INTERNATIONAL JOURNAL OF

SYSTEMATIC BACTERIOLOGY

Vol. 18, No. $3 \quad$ July 1968

pp. $241-252$

Copyright 1968, Iowa State University Press

\title{
PROPOSAL OF A NEW SPECIES PSEUDOMONAS BATHYCETES
}

M. M. Quigley and R.R. Colwell

Department of Biology, Georgetown University

Washington, D. C. 20007

ABSTRACT. Twenty-three strains of bacteria isolated from mudsamples taken in the Pacific Ocean at depths ranging from 9,400 to 10,400 meters have been found to be members of the genus Pseudomonas. From results of Adansonian analysis the strains appear to constitute a new species. Pseudomonas bathycetes n. sp. is therefore proposed and the median organism for the group, strain C $2 M 2$ (A TCC 23597 ), is designated as the type strain. Deoxyribonucleic acid base composition determinations and electron micrographs provide confirmatory evidencefor the identification and classification of $\underline{P}$. bathycetes.

\section{INTRODUCTION}

One of the first applications of numerical taxonomy to the identification and classification of bacteria was a study of marine microorganisms undertaken by Colwell and Liston (1961). Other data have appeared since, notably the investigation of Pfister and Burkholder (1965) who also applied computer taxonomic techniques to the characterization of unknown marine isolates. Recently, marine microbiology studies have been extended to include taxonomic analyses of bacteriological isolates from the true "deep sea," i. e, depths in excess of 6,000 meters (Quigley 1967; Quigley and Colwell 1968). The incentive for such studies was the relative lack of good information concerning deep-sea forms. Other than quantitative estimates of the capabilities of microorganisms present in seawater or marine sediments (Zobell 1954; ZoBell and Morita 1959), no species descriptions are available in the literature for the true deep-sea bacteria. 
The present study is intended as a precise description of the species, Pseudomonas bathycetes n. sp., which represented the major phenetic cluster of a taxonomic analysis of deep-sea bacteria. The bacteria were isolated from sediments collected from the Philippine Trench (9,854 and 9, 443 meters) and the Challenger Deep $(10,373$ meters) in the Marianas Trench of the Pacific Ocean.

\section{MATERIA LS AND METHODS}

Twenty-three isolates were examined. All the isolates included in the study were collected in November, 1964, during the Dodo Expedition by R. Y. Morita, Oregon State University, Corvallis, Oregon, and C.E. ZoBell, Scripps Institution of Oceanography, University of California at San Diego, La Jolla, California. Sampling data are given in Table 1. Methods of sampling and culture procedures have been described elsewhere (Quigley and Colwell 1968).

The maintenance medium employed throughout the studies consisted of: Yeast extract (Difco), 0.3\%; Proteose peptone (Difco), 1.0\%; and a salt solution consisting of, per liter of distilled water: sodium chloride, $2.4 \%$; potas sium chloride, $0.07 \%$; magnesium chloride, $0.53 \%$; and magnesium sulfate, $0.7 \%$; adjusted to $\mathrm{pH} 7.2-7.4$ with sodium hydroxide. Incubation of inoculated test media was at $25^{\circ} \mathrm{C}$. A total of 116 morphological, cultural, physiological and biochemical characteristics was determined for each strain of the species set. The tests and test procedures followed have been cited previously (Quigley and Colwell 1968).

The taxonomic data were coded and transferred to IBM punch cards. Similarity values were computed and phenetic clusters obtained following the method of Colwell and Liston (1961). Feature frequency (Colwell 1964) and median organism calculations (Liston, Wiebe and Colwell 1963) were determined for the cluster output in the course of the computer analysis. The computers used in the study were the IBM 1620 Model II computer with 1311 Disk Pack System and the IBM 360/40 System. Programs written for taxonomic analysis and used in this study were GTP- 2 (Georgetown Taxonomy Program No. 2), GTP-3, GTP-4 and GTP-5. GTP-2 is a program employing a modification of the highest-link sorting method of Sneath (1957) whereby the affinities amongst strains of an analysis set are employed both to determine group saltations and to position strains within a group. GTP-3 provides feature frequency of occurrence for clusters 
Table 1. Sampling data for Pseudomonas bathycetes strains.

\begin{tabular}{|c|c|c|c|c|c|}
\hline $\begin{array}{l}\text { Core } \\
\text { No. }\end{array}$ & $\begin{array}{c}\text { Station } \\
\text { No. } \\
\end{array}$ & Date & Depth & Latitude & Longitude \\
\hline A & 280 & Nov. 25,1964 & $9,854 \mathrm{~m}$ & $10^{\circ} 10^{\prime} \mathrm{N}$ & $126^{\circ} 40^{\prime} \mathrm{E}$ \\
\hline B & 281 & Nov. 25, 1964 & $9,443 \mathrm{~m}$ & $10^{\circ} 3.8^{\prime} \mathrm{it}$ & $126^{\circ} 40^{\prime} \mathrm{E}$ \\
\hline C & 282 & Nov. 28,1964 & $10,373 \mathrm{~m}$ & $11^{\circ} 20^{\prime} \mathrm{N}$ & $142^{\circ} 19^{\prime} \mathrm{E}$ \\
\hline
\end{tabular}

Table 2. Frequency of occurrence of morphological features for Pseudomonas bathycetes.

$\begin{array}{lc}\text { Feature } & \text { Frequency } \\ \text { Singles } & +(1.0) \\ \text { Width } 0.2-0.6 \mu & +(1.0) \\ \text { Gram negative } & +(1.0) \\ \text { Rods } & +(1.0) \\ \text { Pairs } & +(0.9) \\ \text { Length } 0.2-0.6 \mu & +(0.9) \\ \text { Round end } & \pm(0.7) \\ \text { Motile } & \pm(0.7) \\ \text { Polar flagella } & \pm(0.7) \\ \text { Tapered end } & \pm(0.4) \\ \text { Chains } & \pm(0.3) \\ \text { Filaments } & -(0.2) \\ \text { Curved rods } & -(0.1) \\ \text { Length 0.6-1.2 } & -(0.1) \\ \text { Peritrichous flagella } & -(0.1) \\ \text { Spiral rods } & -(0.0) \\ \text { Oval (spheres) } & -(0.0) \\ \text { Refractile } & -(0.0)\end{array}$


and GTP- 4 computes for each cluster the hypothetical median organism. The comparison of each strain of the cluster with the hypothetical median permits selection of a strain with the highest similarity to the computed median as the "typical" or type strain. GTP-5 output is the full S-value matrix ordered by GTP-2. The programs have been documented for the IBM 1620 Computer Users' Group and are available from the authors (RRC) or directly from the Georgetown University Computation Center, Washington, D. C. 20007, U.S.A.

\section{RESULTS AND DISCUSSION}

In the initial analysis, 38 strains were examined. Seven phenetic clusters were distinct at $65 \% \mathrm{~S}$ (similarity level) and these have been described elsewhere (Quigley and Colwell 1968). Clusters I and II were found in the earlier stages to merge at $76 \% \mathrm{~S}$ and have, therefore, been treated as a species cluster (Fig. 1 ). A value of $S \geq 75 \%$ has been suggested as a possible species level of similarity (Colwell and Liston 1961; Liston, Wiebe and Colwell 1963).

Feature frequencies computed for the set of 23 strains are presented in Tables $2,3,4$ and 5 . In general, the strains are Gram-negative, nonpigmented, short, slender rods occurring as singles and pairs, oxidase positive, capable of growth at temperatures ranging from $0-37^{\circ} \mathrm{C}$, and at salt concentrations of $0-10 \% \mathrm{NaCl}$. The strains were oxidative or not reactive in glucose, and were capable of growth on a vitamin-free casamino acids medium, with basal salts solution as diluent. The strains did not demonstrate a requirement for natural or synthetic seawater for growth but growth was stimulated when a seasalts medium was provided. The arginine, ornithine and lysine decarboxylase reactions were negative. Only glucose and sucrose, of the carbohydrates tested, were utilized (oxidatively) by the 23 strains.

The strains were polarly flagellated when studied by flagella staining technique. However, when examined under the electron microscope, some of the strains were found to be polarly flagellated after 24 hours growth in a seasalts-based medium (Fig. 2) and peritrichously flagellated if examined after 48 hours or later (Fig. 3). Other investigators have reported similar observations for marine pseudomonads (Buttiaux and Voisin 1958/1959; Leifson 1963).

The median organism calculated for the strain set was C2M2 (A TCC 23597), which demonstrated a value of $95 \% \mathrm{~S}$ 
Table 3. Frequency of occurrence of cultural features for Pseudomonas bathycetes.

\begin{tabular}{lc}
\hline Feature & Frequency \\
Convex colony & $+(1.0)$ \\
Opaque colony & $+(1.0)$ \\
Entire edge & $+(1.0)$ \\
Off-white colony & $+(1.0)$ \\
Even turbidity in broth & $+(0.9)$ \\
Medium colony (2-5 mm) & $\pm(0.6)$ \\
Moderate turbidity in broth & $\pm(0.6)$ \\
Small colony (l-2 mm) & $\pm(0.3)$ \\
Pellicle in broth & $-(0.2)$ \\
Slight turbidity in broth & $-(0.2)$ \\
Heavy turbidity in broth & $-(0.2)$ \\
Granular turbidity in broth & $-(0.1)$ \\
Rough colony & $-(0.0)$ \\
Translucent colony & $-(0.0)$ \\
Spreading on agar & $-(0.0)$ \\
Diffusible pigment produced & $-(0.0)$ \\
Visible insoluable pigment & $-(0.0)$ \\
Fluorescence under U/v light & $-(0.0)$ \\
& \\
\hline
\end{tabular}

Table 4. Sensitivity of Pseudomonas bathycetes to antibiotics and antibacterial agents.

\begin{tabular}{lc}
\hline Feature (Sensitivity) & Frequency \\
\hline Dihydrcstreptomycin 10 ug & $+(1.0)$ \\
Chloromycetin 30 ug & $+(1.0)$ \\
Kanamycin 30 ug units & $+(1.0)$ \\
Polymyxin B 300 units & $+(1.0)$ \\
Terramycin 30 ug & $+(0.9)$ \\
Novobiocin 30 ug & $+(0.8)$ \\
Penicillin 10 units & $\pm(0.7)$ \\
Erythromycin 15 ug & $\pm(0.7)$ \\
Tetracycline 30 ug & $\pm(0.7)$ \\
Aureomycin 30 ug & $\pm(0.5)$ \\
Pteridine 0/129 & $-(0.1)$ \\
\hline
\end{tabular}


Table 5. Frequency of occurrence of biochemical features for Pseudomonas bathycetes.

\begin{tabular}{|c|c|}
\hline Feature & Frequency \\
\hline Oxidase positive & $+(1.0)$ \\
\hline Glucose + iodoacetate $\rightarrow$ Growth & $+(0.9)$ \\
\hline Lipase prescnt: Tween 60 & $+(0.9)$ \\
\hline Lipase present: Treen co & $+(0.8)$ \\
\hline Lipase present: Tween 40 & $\pm(0.7)$ \\
\hline Catalase positive & $\pm(0.7)$ \\
\hline Glucose acica aerobic & $\pm(0.6)$ \\
\hline Sucrcse acid aerobic & $\pm(0.6)$ \\
\hline Glucose + iodcacetate $\rightarrow$ Acid & $\pm(0.6)$ \\
\hline Litmus mil: alkaline & $\pm(0.5)$ \\
\hline Litmus milk reàuced & $\pm(0.5)$ \\
\hline Lipase present: Tween 80 & $\pm(0.4)$ \\
\hline Lecithinase present & $\pm(0.4)$ \\
\hline $\mathrm{NC}_{3}$ reduced & $\pm(0.3)$ \\
\hline Liumus milk acid & $-(0.2)$ \\
\hline Galactose acid aerobic & $-(0.1)$ \\
\hline Waltcse acid aerooic & $-(0.1)$ \\
\hline Starch hyärolyzed & $-(0.1)$ \\
\hline Citrate positive & $-(0.1)$ \\
\hline Gelatin liquefied & $-(0.1)$ \\
\hline Glucose acid anaerobic & $-(0.0)$ \\
\hline Glucose gas & $-(0.0)$ \\
\hline Lactose acid & $-(0.0)$ \\
\hline Mannitol acid & $-(0.0)$ \\
\hline Indole produced & $-(0.0)$ \\
\hline Methyl red & $-(0.0)$ \\
\hline Voges-Prosliauer & $-(0.0)$ \\
\hline $\mathrm{IN}_{2}$ reduced & $-(0.0)$ \\
\hline Litmus mill: peptonized & $-(0.0)$ \\
\hline Arcinine decarbonylase & $-(0.0)$ \\
\hline Lysine decarboxylase & $-(0.0)$ \\
\hline Ornithine àecarboxylase & $-(0.0)$ \\
\hline Flucrescence in Paton's medium & $-(0.0)$ \\
\hline
\end{tabular}




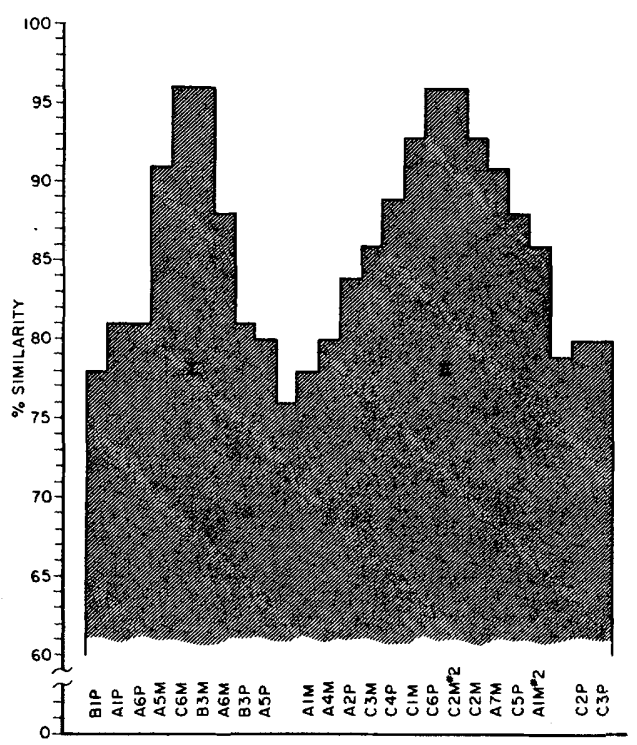

Figure 1. Phenetic clustering of the 23 strains of Pseudomonas bathycetes by unweighted-pair, highest linkage sorting of similarity values.

when compared with the hypothetical median organism. The over-all guanine + cytosine content of the DNA was determined by both buoyant density measurements in cesium chloride and thermal denaturation (Citarella and Colwell 1966). G+C value for C2M2, the type strain, was found to be $57 \%\left(\rho=1.716, \mathrm{~T}_{\mathrm{m}}=93^{\circ} \mathrm{C}\right)$.

Consultation of the literature for published descriptions to fit the deepsea pseudomonads was unsuccessful. Pfister and Burkholder (1965), who applied computer techniques to the analysis of 151 bacterial strains isolated from the Antarctic Sea and from waters in the vicinity of Puerto Rico, demonstrated that organisms occurring in different areas of the open ocean may be profitably studied by means of computer analysis. The 151 marine strains of the analysis carried out by Pfister and Burkholder formed nine distinct clusters, not identified explicitly by them, but designated as Groups I-IX. None of these groups corresponded to $\underline{P}$. bathycetes. 


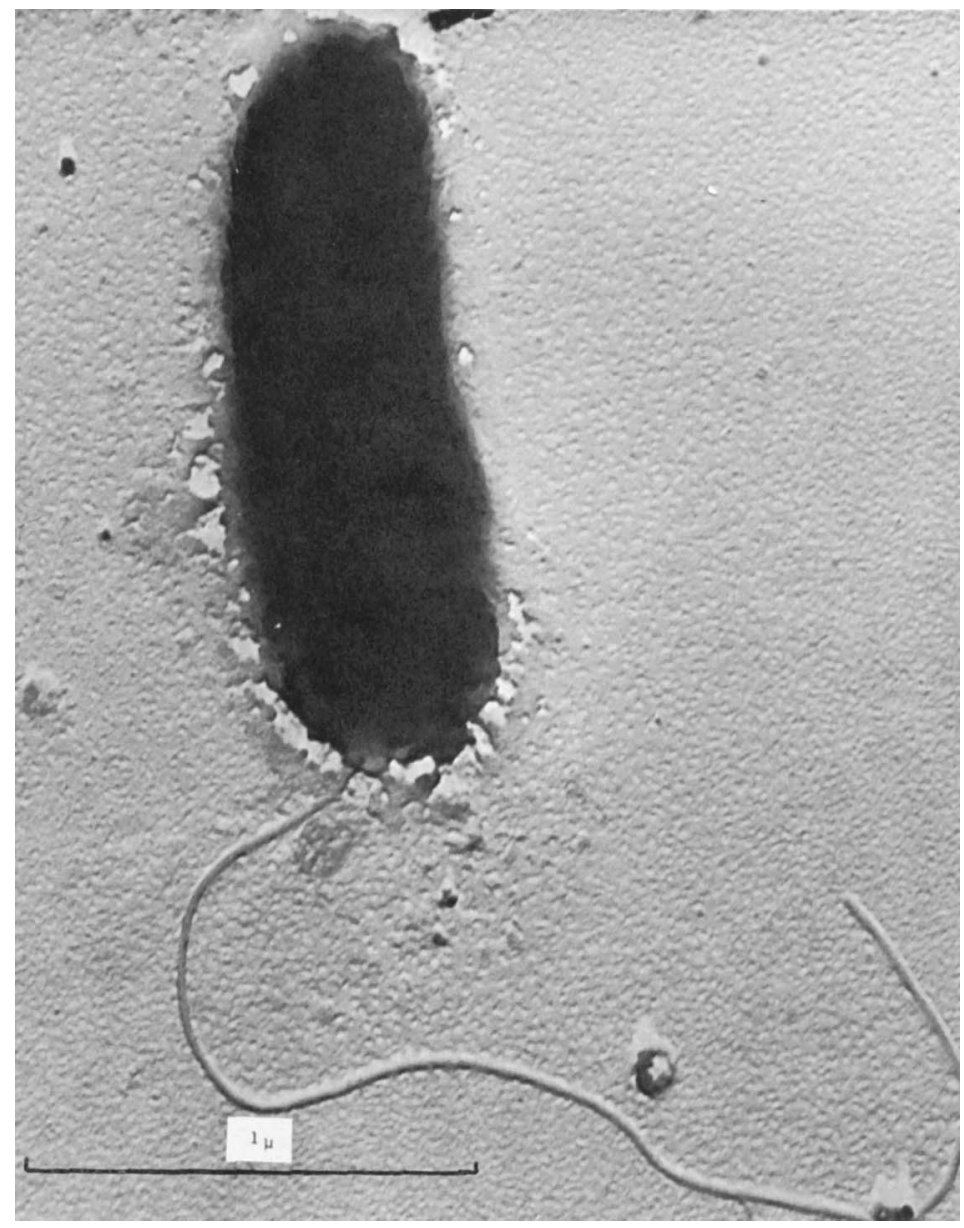

Figure 2. Electron micrograph of a chromium shadowed preparation of strain C2M2, the median organism of Pseudomonas bathycetes, exhibiting polar flagellation. 24 hour seawater broth culture. $(\mathrm{X} 40,500)$. 


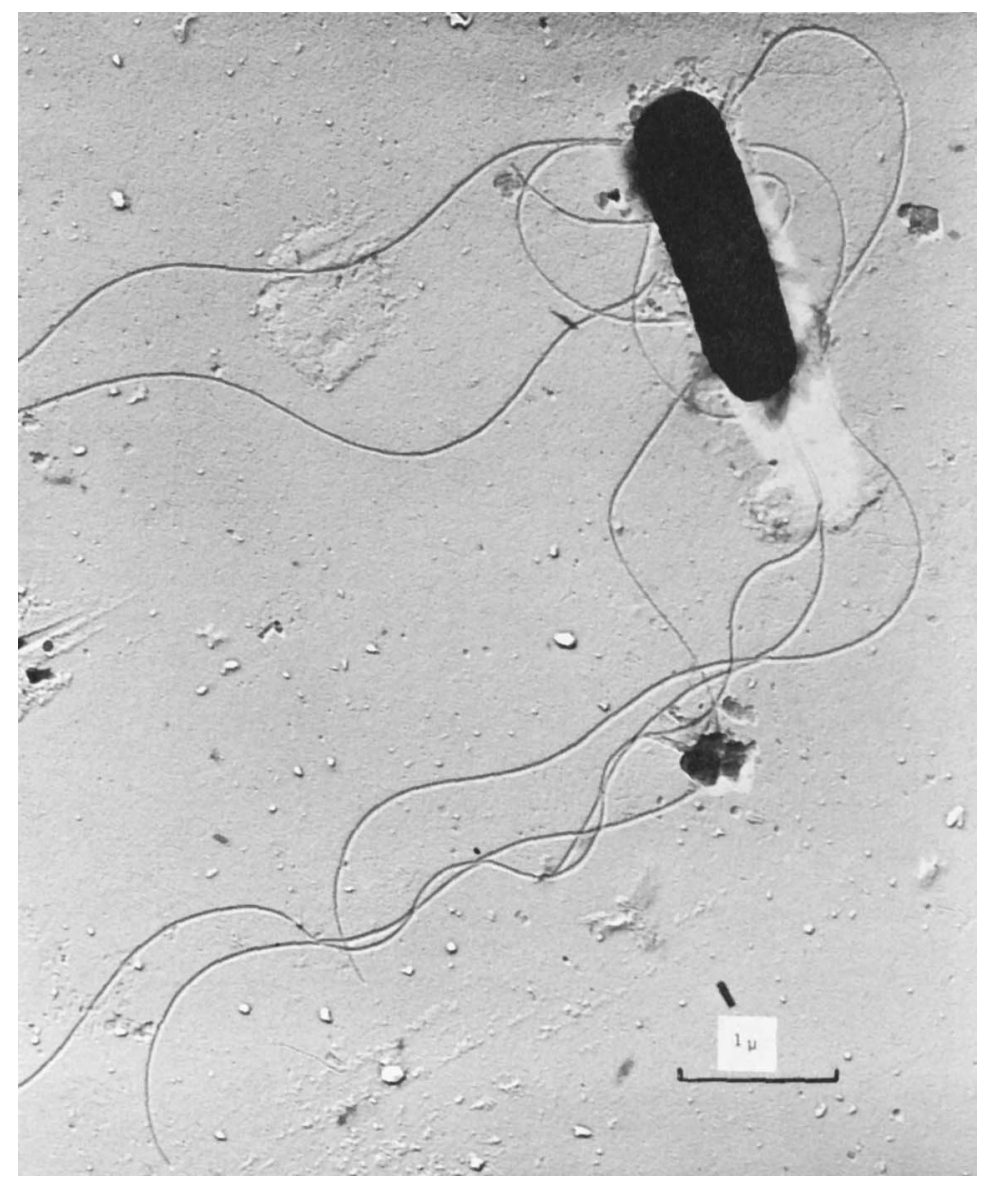

Figure 3. Electron micrograph of a chromium shadowed preparation of strain $\mathrm{C} 2 \mathrm{M} 2$, the median organism of Pseudomonas bathycetes, exhibiting peritrichous flagellation. 48 hour seawater broth culture. $(\mathrm{X} 16,500)$. 
The 23 strains of $P$. bathycetes were compared by computer with a set of 132 previously analyzed marine strains (Colwell and Gochnauer 1963; Colwell, Gochnauer and Quigley 1967). Similarity values and phenetic clusters were calculated thus for a total of 170 isolates. At $S \geq 75 \%$ (species level of similarity) the $23 \mathrm{P}$. bathycetes strains clustered separately from the 147 other strains. However at $S$ values between $70 \%$ and $74 \%$, the $P$. bathycetes strains clustered with several known Pseudomonas strains, including named, culture collection strains, thus providing strong evidence of membership within the genus Pseudomonas.

Very few descriptions of marine species of bacteria are available in the literature and from the available descriptions little information can be gleaned for identification and classification purposes. Either the descriptions are scanty or the media employed cannot be duplicated. Comparison of data for $P$. bathycetes with the descriptions of marine Pseudomonas spp. cited in Bergey's Manual of Determinative Bacteriology (Breed et al. , 1957), by ZoBell and Upham (1944) and by Shewan (1963) do not reveal species level of similarity with the deep-sea forms. Since the strains of $P$. bathycetes are barotolerant, i.e., able to grow in 1100 atm. (in situ pressures), a property not shared by terrestrial and shallow water species, and since as a species group, $P$. bathycetes does not appear to be similar to any species described in the literature, it appears justifiable to propose $\underline{P}$. bathycetes as a new species.

\section{ACKNOW LEDGMENT}

The authors wish to express their gratitude to Dr. G. B. Chapmen who so kindly provided advice and assistance with the electron microscopy, to Rev. Stephen Winters, S. J. for helpful discussion of questions pertaining to nomenclature, and to Miss T.E. Lovelace for her excellent technical assistance. Also, the collaboration of Drs. C. E. ZoBell and R. Y. Norita in providing the cultures is gratefully acknowledged.

This investigation was supported by Contract Nonr -4810 (00) (NR 103-667) between the Office of Naval Research, Department of the Navy, and Georgetown University. 


\section{LITERATURE CITED}

Buttiaux, R. and C. Voisin. 1958/59. Coexistence de cils polaires et peritriches chez un bacille halophile. Influence de la composition du milieu sur cette association. Ann. Inst. Pasteur, Lille X:151-158.

Breed, R.S., E.G.D. Murray and N.R. Smith. 1957. Bergey's Manual of Determinative Bacteriology. 7th ed. Williams and Wilkins Co., Baltimore, Maryland.

Citarella, R.V. and R.R. Colwell. 1966. DNA base composition of Achromobacter liquefaciens (Tulecke et al.). Can. J. Microbiol. 12:418-420.

Colwell, R. R. 1964. A study of the features used in the diagnosis of Pseudomonas aeruginosa. J. Gen. Microbiol. 37: $181-194$.

and M. Gochnauer. 1963. The taxonomy of marine bacteria. Bacteriol. Proc. G68. and M. M. Quigley. 1967. Application of computers in marine microbiology. Soc. Indust. Microbiol. Newsl. 17:20-21.

and J. Liston. 1961. Taxonomic relationships among

the pseudomonads. J. Bacteriol. 82:1-14.

Leifson, E. 1963. Mixed polar and peritrichous flagellation of marine bacteria. J. Bacteriol. 86:166-167.

Liston, J., W. Wiebe and R. R. Colwell. 1963. Quantitative approach to the study of bacterial species. J. Bacteriol. 85:1061-1070.

Pfister, R. M. and P.R. Burkholder. 1965. Numerical taxonomy of some bacteria isolated from Antarctic and tropical seawaters. J. Bacteriol. 90:863-872.

Quigley, M. M. 1967. Properties of bacteria isolated from deep-sea sediments. Bachelor of Science Thesis. Georgetown University, Washington, D.C. and R.R. Colwell. 1968. Properties of bacteria

isolated from deep-sea sediments. J. Bacteriol. 95:211220.

Shewan, J.M. 1963. The differentiation of certain genera of Gram-negative bacteria frequently encountered in marine environments. Marine Microbiology, C. H. Oppenheimer, Ed., pp. 499-521.

Sneath, P.H.A. 1957. The application of computers to taxonomy. J. Gen. Microbiol. 17:201-226.

ZoBell, C.E. 1954. The occurrence of bacteria in the deep sea and their significance for animal life. Intl. Union Biol. Sci., Series B, No.16, pp. 20-24. 
and R.Y. Morita. 1959. Deep-sea bacteria.

Galathea Report, Scientific Results of the Danish DeepSea Round the World Expedition 1950-1952, Copenhagen 1:139-154.

and H.C. Upham, 1944. A list of marine bacteria including descriptions of sixty new species. Bull. Scripps Institute Oceanog. U. Cal. 5:239-292. 